This article was downloaded by: [National Taiwan University]

On: 11 June 2009

Access details: Access Details: [subscription number 905688742]

Publisher Taylor \& Francis

Informa Ltd Registered in England and Wales Registered Number: 1072954 Registered office: Mortimer House, 37-41 Mortimer Street, London W1T 3JH, UK

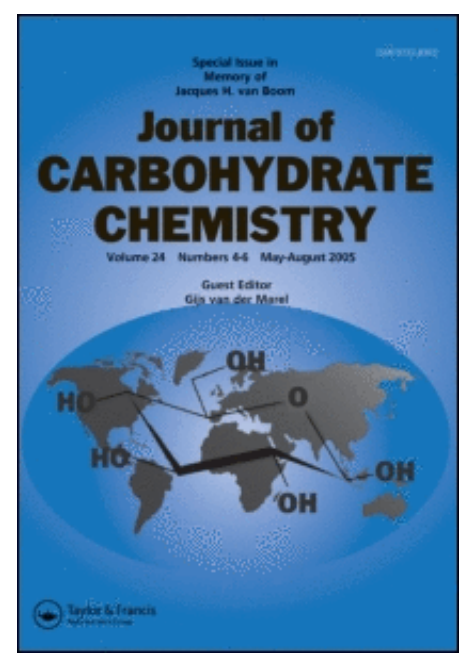

\title{
Journal of Carbohydrate Chemistry
}

Publication details, including instructions for authors and subscription information:

http://www.informaworld.com/smpp/title content=t713617200

\section{Preparation of Hepta-O-Acetylsucroses and Hexa-O-Acetylsucroses by Enzymatic Hydrolysis \\ Kung-Yao Chang; Shih-Hsiung Wu; Kung-Tsung Wang}

Online Publication Date: 01 January 1991

To cite this Article Chang, Kung-Yao, Wu, Shih-Hsiung and Wang, Kung-Tsung(1991)'Preparation of Hepta-O-Acetylsucroses and Hexa-O-Acetylsucroses by Enzymatic Hydrolysis',Journal of Carbohydrate Chemistry, 10:2,251 — 261

To link to this Article: DOI: 10.1080/07328309108543904

URL: http://dx.doi.org/10.1080/07328309108543904

\section{PLEASE SCROLL DOWN FOR ARTICLE}

\footnotetext{
Full terms and conditions of use: http://www.informaworld.com/terms-and-conditions-of-access.pdf

This article may be used for research, teaching and private study purposes. Any substantial or systematic reproduction, re-distribution, re-selling, loan or sub-licensing, systematic supply or distribution in any form to anyone is expressly forbidden.

The publisher does not give any warranty express or implied or make any representation that the contents will be complete or accurate or up to date. The accuracy of any instructions, formulae and drug doses should be independently verified with primary sources. The publisher shall not be liable for any loss, actions, claims, proceedings, demand or costs or damages whatsoever or howsoever caused arising directly or indirectly in connection with or arising out of the use of this material.
} 
PREPARATION OF HEPTA-O-ACETYLSUCROSES AND HEXA-O-ACETYLSUCROSES BY ENZYMATIC HYDROLYSIS

\author{
Kung-Yao Chang, Shih-Hsiung $W^{*}$ and Kung-Tsung Wang \\ Institute of Biological Chemistry, Academia Sinica \\ and \\ Graduate Institute of Biochemical sciences, \\ National Taiwan University \\ P.O.Box. 23-106, Taipei, Taiwan, ROC
}

Received June 22, 1990 - Final Form November 28, 1990

\title{
$\underline{\text { ABSTRACT }}$
}

Octa-o-acetylsucrose (1) was regioselectively hydrolyzed by the lipase AK from Pseudomonas sp. in aqueous buffer and two hepta-o-acetylsucroses and two hexa-o-acetylsucroses were obtained by column purification. After analysis by NMR methods, four products were shown to be $3,4,6,1^{\prime}, 3^{\prime}, 4^{\prime}, 6^{\prime}$-hepta-o-acetylsucrose (2), $2,3,4,6,1,3,, 6$-hepta-o-acetylsucrose (3) , $3,4,6,1^{\prime}, 3^{\prime}, 6^{\prime}$-hexa-o-acetylsucrose (4) and $2,3,4,6,3^{\prime}, 6^{\prime}$-hexao-acetylsucrose ( $\underline{5})$.

\section{INTRODUCTION}

Synthetic sucrose esters have a lot of potential applications in cosmetics, plasticizers and food preservatives. ${ }^{1}$ On the other hand, naturally occurring sucrose esters secreted from glandular trichomes that cover the foliage of many wild potato species (Solanum $\mathrm{sp}$ ) have special biological functions for entrapping arthropod pests and might play an important role in the development of the insect-resistant plants. ${ }^{2-4}$ Because of their importance, the preparation of sucrose esters has been 


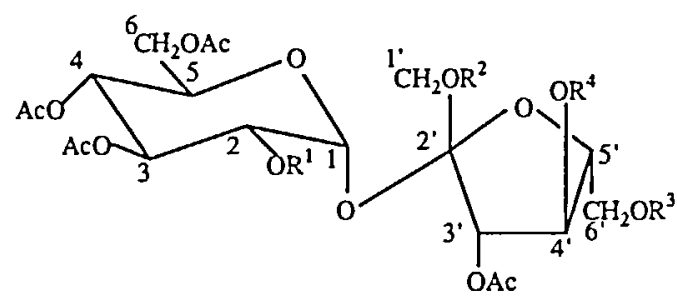

\begin{tabular}{|c|c|c|c|c|}
\hline & $\mathrm{R}^{1}$ & $\mathrm{R}^{2}$ & $\mathrm{R}^{3}$ & $R^{4}$ \\
\hline 1 & $A C$ & $A c$ & $A C$ & $A C$ \\
\hline$\underline{2}$ & $\mathrm{H}$ & $\mathrm{Ac}$ & $\mathrm{Ac}$ & $\mathrm{Ac}$ \\
\hline 3 & $\mathrm{AC}$ & $\mathrm{Ac}$ & $A c$ & $\mathrm{H}$ \\
\hline 4 & $\mathbf{H}$ & $\mathrm{Ac}$ & $\mathrm{Ac}$ & $\mathrm{H}$ \\
\hline 5 & $\mathrm{Ac}$ & $\mathrm{H}$ & $\mathrm{Ac}$ & $\mathrm{H}$ \\
\hline 6 & $\mathrm{Ac}$ & $\mathrm{H}$ & $\mathrm{H}$ & $\mathbf{H}$ \\
\hline
\end{tabular}

Scheme I : sucrose esters ( $\underline{1})$ to ( $\underline{6})$

widely investigated by chemical methods. ${ }^{5}$ However, it is still tedious and difficult to obtain sucrose derivatives where the hyaroxyl groups of glucose moiety are esterified. Lipases (triacylglycerol ester hydrolases, E. C. 3.1.1.3), because of their high enantioselectivity, ${ }^{6-10}$ have been widely used in the preparation of chiral synthons and optically active compounds. Having a broad substrate specificity and being active in interfacial oil-water microemulsions or nonpolar solvents, lipases were also used in the regioselective hydrolysis of acylated glycosides and the regioselective esterification of sugars in organic solvents.11-20 In this article, the regioselective hydrolysis of lipase $\mathrm{AK}$ toward octa-0acetylsucrose (1) as a model substrate. was examined.

\section{RESULTS AND DISCUSSION}

The treatment of octa-o-acetylsucrose (1) with the lipase AK from Pseudomonas sp. was carefully studied and four products were isolated by silica gel column chromatogragh (purification conditions were described in the Experimental). Their structures are $3,4,6,1^{\prime}, 3^{\prime}, 4^{\prime}, 6^{\prime}$-hepta-o-acetylsucrose (ㅁ) (8 8 of the yield), $2,3,4,6,1^{\prime}, 3^{\prime}, 6^{\prime}$-hepta-o-acetylsucrose $(\underline{3}) \quad(20 \quad \delta)$, $3,4,6,1^{\prime}, 3^{\prime}, 6^{\prime}$-hexa-o-acetylsucrose $(\underline{4})(148)$ and $2,3,4,6,3^{\prime}, 6^{\prime}-$ hexa-ㅁ-acetylsucrose ( $\underline{5})$ (41 $z$ ) (Scheme I and II).

The structures of four products were determined from their ${ }^{1} \mathrm{H}$ NMR spectra using decoupling techniques and by comparison of their $2 \mathrm{D}^{1} \mathrm{H}^{-1} \mathrm{H}$ COSY spectra with that of 1 and published spectra 


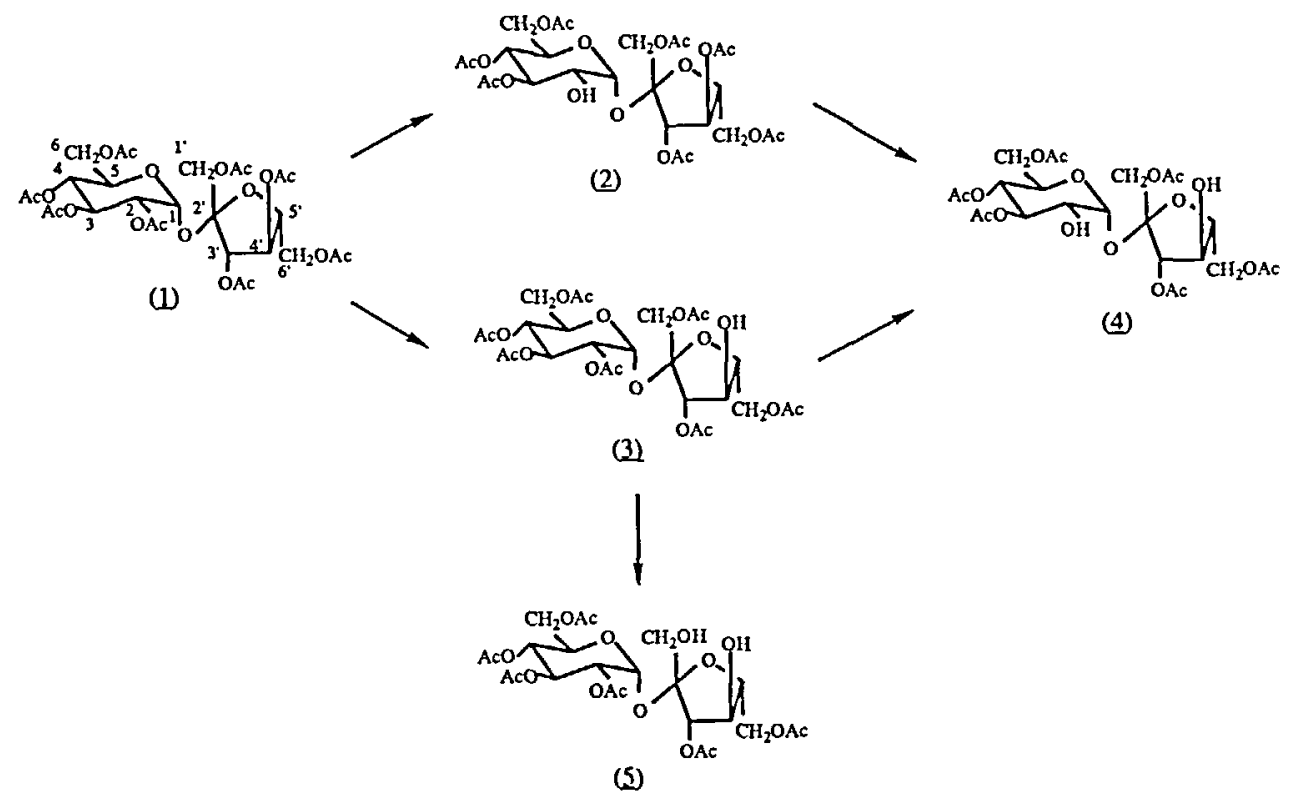

Scheme II : Hydrolysis of Octa-O-acetylsucrose by Lipase AK

of partially acetylated sucrose derivatives. The complete assignment of ${ }^{1} \mathrm{H}$-NMR signals of octa-o-acetylsucrose have been reported $^{21}$ and on the basis of chemical shift data, the signals of the a-proton in primary $\left(\mathrm{CH}_{2}^{*} \mathrm{OAC}\right.$ ) and secondary ( $\mathrm{CH}^{*} \mathrm{OAC}$ ) esters and the $\beta$-proton $\left(\mathrm{CH}^{*}\right.$-CHOAC) shift upfield about $1.15,0.65$ and $0.25 \mathrm{ppm}$, respectively, after deacylation. The results of NMR measurements are listed in Tables $I$ and $I I$. In the case of compound $\underline{2}$, the $\mathrm{H}-2$ signal shifted upfield from 4.90 where it usually occurs in 1 to around $3.70 \mathrm{ppm}$ and its assignment was also confirmed by a decoupling technique (Fig 1).

The chemical shifts of $\underline{3}$ are in accordance with the NMR data of $2,3,4,6,1^{\prime}, 3^{\prime}, 6^{\prime}$-hepta-o-acetylsucrose, which was the main product of hydrolysis of 1 by the lipase from candida cylindracea. ${ }^{19}$ The $\mathrm{H}-4$ ' signal of 3 shifted from 5.43 to the crowded $4.3-4.4 \mathrm{ppm}$ region and the $\mathrm{H}-3^{\prime}$ signal of $\underline{3}$ shifted upfield from 5.45 in 1 to $5.21 \mathrm{ppm}$ due to the effect of deacylation at the 4'-position (Fig. 2A). Based on the assignments in the NMR spectra of $\underline{2}$ and $\underline{3}$ and the $2 \mathrm{D}{ }^{1} \mathrm{H}-{ }^{1} \mathrm{H}$ COSY 
TABLE 1. ${ }^{1} \mathrm{H}-\mathrm{NMR}$ data for Compound $\underline{1}-\underline{5}$

\begin{tabular}{|c|c|c|c|c|c|}
\hline Compound & $\underline{1}$ & $\underline{2}$ & $\underline{3}$ & $\underline{4}$ & $\underline{5}$ \\
\hline $\begin{array}{l}H-1 \\
H-2 \\
H-3 \\
H-4 \\
H-5 \\
H-6 a \\
H-6 \beta \\
H-1^{\prime} a \\
H-1^{\prime}, \beta \\
H-3 ! \\
H-4 \\
H-5^{\prime} \\
H-6^{\prime} \alpha \\
H-6^{\prime} \beta\end{array}$ & $\begin{array}{l}5.69 \\
4.87 \\
5.44 \\
5.08 \\
4.28 \\
4.14 \\
4.28 \\
4.17 \\
4.17 \\
5.47 \\
5.36 \\
4.21 \\
4.29 \\
4.35\end{array}$ & $\begin{array}{c}5.52 \\
3.70 \\
5.13 \\
5.01 \\
4.20 \\
4.10-4.30 \\
4.10-4.30 \\
4.20-4.40 \\
4.20-4.40 \\
5.35-5.40 \\
5.35-5.40 \\
4.20 \\
4.30-4.45 \\
4.30-4.45\end{array}$ & $\begin{array}{c}5.65 \\
4.87 \\
5.41 \\
5.00 \\
4.20 \\
4.20-4.35 \\
4.20-4.35 \\
4.30-4.40 \\
4.30-4.40 \\
5.21 \\
4.25 \\
4.00-4.25 \\
4.30-4.40 \\
4.30-4.40\end{array}$ & $\begin{array}{c}5.54 \\
3.66 \\
5.16 \\
4.95 \\
4.15-4.30 \\
4.10-4.40 \\
4.10-4.40 \\
4.15-4.30 \\
4.15-4.30 \\
5.18 \\
4.30-4.40 \\
3.95-4.05 \\
4.20-4.40 \\
4.20-4.40\end{array}$ & $\begin{array}{l}5.63 \\
4.88 \\
5.41 \\
5.01 \\
4.05-4.25 \\
4.05-4.30 \\
4.05-4.30 \\
3.54 \\
3.63 \\
5.18 \\
4.35-4.40 \\
4.00-4.05 \\
4.10-4.40 \\
4.10-4.40\end{array}$ \\
\hline $\begin{array}{l}J_{1,2} \\
J_{2,3} \\
J_{3,4} \\
J_{4,5} \\
J_{1} \cdot a, 1 \cdot 3 \\
J_{3} \cdot 4^{\circ} \\
J_{4} \cdot 5^{\circ}\end{array}$ & & $\begin{array}{r}3.7 \\
10.3 \\
9.7 \\
9.7 \\
- \\
- \\
7.7\end{array}$ & $\begin{array}{r}3.7 \\
10.3 \\
9.7 \\
9.7 \\
- \\
7.8 \\
-\end{array}$ & $\begin{array}{l}3.8 \\
10.1 \\
9.8 \\
9.8 \\
- \\
8.4 \\
-\end{array}$ & $\begin{array}{r}3.7 \\
10.3 \\
9.7 \\
9.7 \\
12.3 \\
7.2 \\
-\end{array}$ \\
\hline
\end{tabular}

a. measured in $\mathrm{CDCl}_{3}$

b. chemical shifts in ppm; coupling constants in $\mathrm{Hz}$.

TABLE 2. ${ }^{13} \mathrm{C}$ NMR Chemical shifts (ppm) for Compounds $\underline{1}, \underline{2}, \underline{3}$ and $\underline{5}$.

\begin{tabular}{|c|c|c|c|c|}
\hline Compound & $\underline{1}$ & $\underline{2}$ & $\underline{3}$ & $\underline{5}$ \\
\hline $\begin{array}{l}c-1 \\
c-2 \\
c-3 \\
c-4 \\
c-5 \\
c-6 \\
c-1 ! \\
c-2, \\
c-3 ' \\
c-4 \\
c-5 ! \\
c-6 !\end{array}$ & $\begin{array}{r}89.93 \\
70.26 \\
69.61 \\
68.17 \\
68.50 \\
61.75 \\
62.85 \\
104.02 \\
75.68 \\
74.98 \\
79.14 \\
63.63\end{array}$ & $\begin{array}{r}92.48 \\
70.50 \\
73.09 \\
67.70 \\
68.95 \\
61.73 \\
63.11 \\
103.92 \\
76.46 \\
74.82 \\
79.15 \\
63.36\end{array}$ & $\begin{array}{r}88.89 \\
70.03 \\
69.69 \\
68.24 \\
68.53 \\
62.12 \\
63.41 \\
102.71 \\
78.33 \\
73.00 \\
80.30 \\
63.98\end{array}$ & $\begin{array}{r}89.02 \\
70.20 \\
69.87 \\
68.22 \\
68.61 \\
62.15 \\
64.25 \\
104.30 \\
78.86 \\
73.18 \\
80.37 \\
63.53\end{array}$ \\
\hline
\end{tabular}

a. measured in $\mathrm{CDCl}_{3} \cdot{ }^{13} \mathrm{C}$ NMR spectra were based on the ${ }^{1} \mathrm{H}-{ }^{13} \mathrm{C}$ 2D-COSY spectra (Fig 4.) 
A)

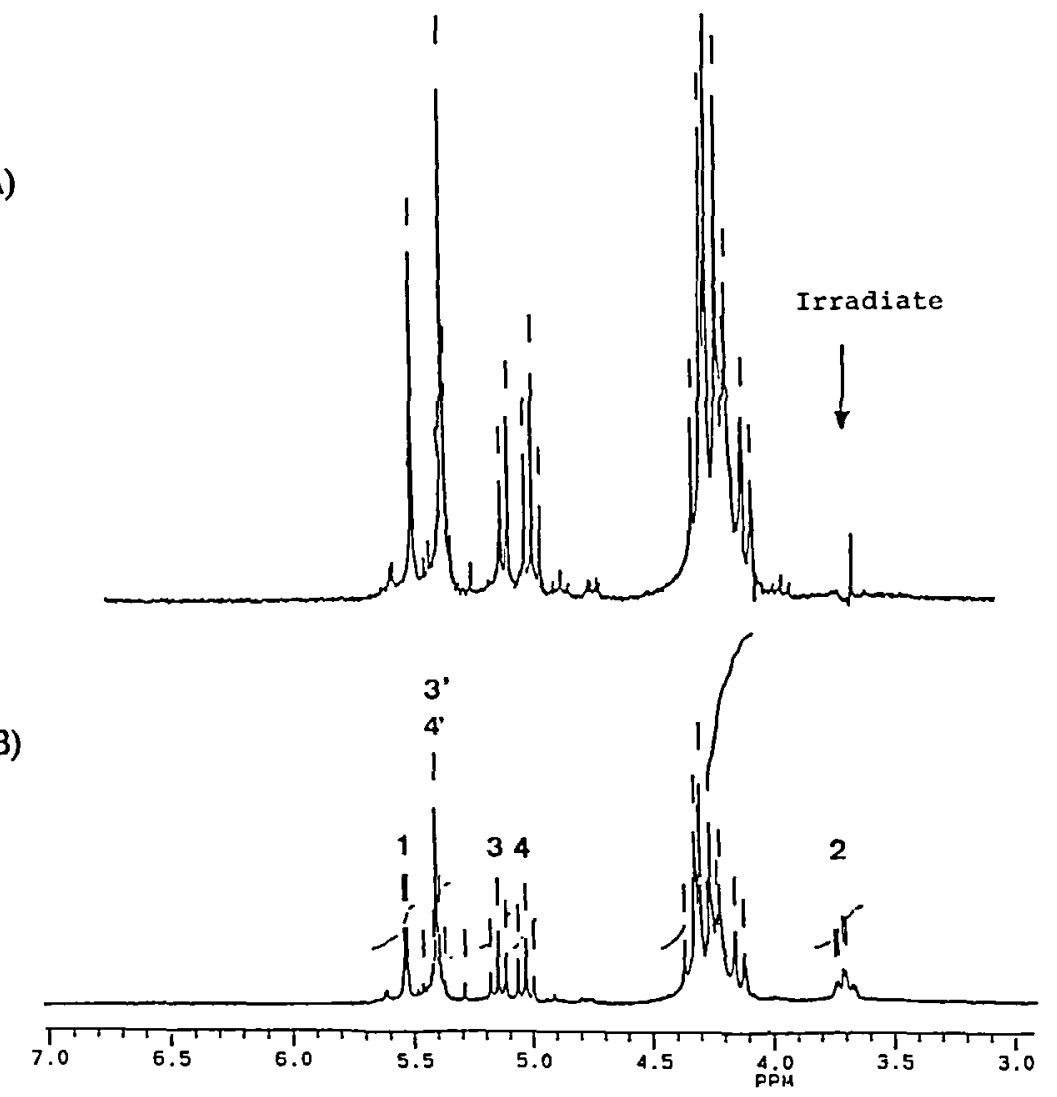

FIG. 1. ${ }^{1} \mathrm{H}$-NMR spectrum of compound $\underline{2}(B)$ and partially decoupled spectrum of $\underline{2}(A)$.

spectra of $\underline{4}$ (Fig.3), the structure of $\underline{4}$ was determined to be $3,4,6,1^{\prime}, 3^{\prime}, 6^{\prime}$-hexa-O-acetylsucrose. As shown in ${ }^{1} \mathrm{H}$-NMR spectrum of 4 ( $F i g .2 B$ ), the signals of $\mathrm{H}-3$ and $\mathrm{H}-3$ ' shifted upfield from 5.45 to $5.18 \mathrm{ppm}$ because of the deacylation of the 2 and $4^{\prime}$ positions. As for compound $\underline{5}$, the two doublet signals shifted out of the crowded $(4.04-4.40)$ to $3.54-3.63 \mathrm{ppm}$ region and the $\mathrm{H}-3^{\prime}$ signal shifted upfield from 5.45 (in 1) to $5.21 \mathrm{ppm}$, apparently indicating deacylation of the $1^{\prime}$ and $4^{\prime}$ positions (Fig. 2C). Comparing the ${ }^{1} \mathrm{H}$-NMR data of $2,3,4,6,3^{\prime}$-penta-oacetyl-sucrose $(\underline{6})^{19}$ with that of $\underline{5}$ and considering this structure determination seems quite reasonable.

The trityl ethers and acetals of sucrose have generally been used as precursors for the synthesis of partially acylated 
A)

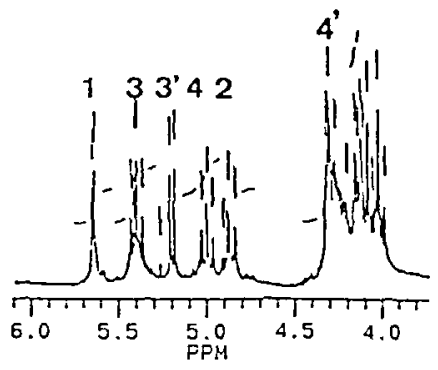

B)

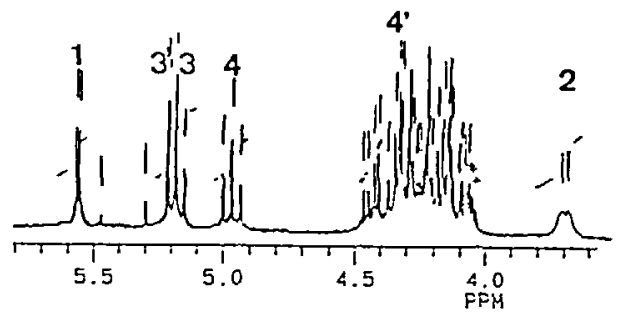

C)

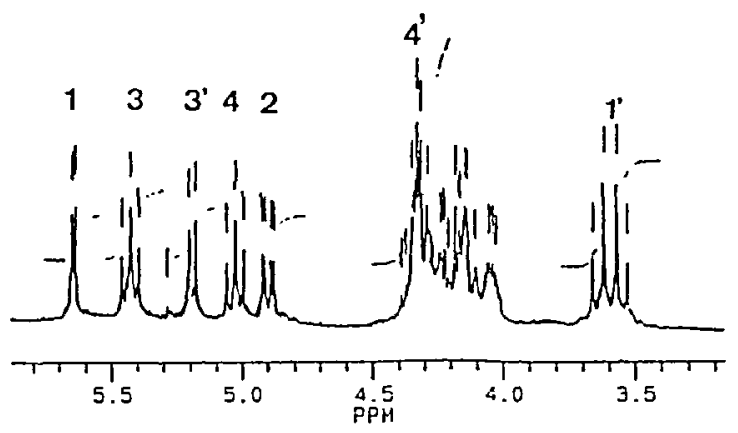

FIG. 2. ${ }^{1} \mathrm{H}-\mathrm{NMR}$ spectra of compound $\underline{3}$ (A) compound $\underline{4}(\mathrm{~B})$ and compound $\underline{5}$ (C).

derivatives of sucrose. However, these methods were inefficient and tedious in the processes of selective tritylation, full acetylation and then detritylation. ${ }^{5}$ Alternatively, several hepta-ㅁ-acetylsucroses such as $\underline{2}, 2,3,4,6,1^{\prime}, 3^{\prime}, 4^{\prime}$-hepta- $\underline{0}-$ acetylsucrose, $2,3,6,1^{\prime}, 3^{\prime}, 4^{\prime}, 6^{\prime}$-hepta-o-acetylsucrose and a 


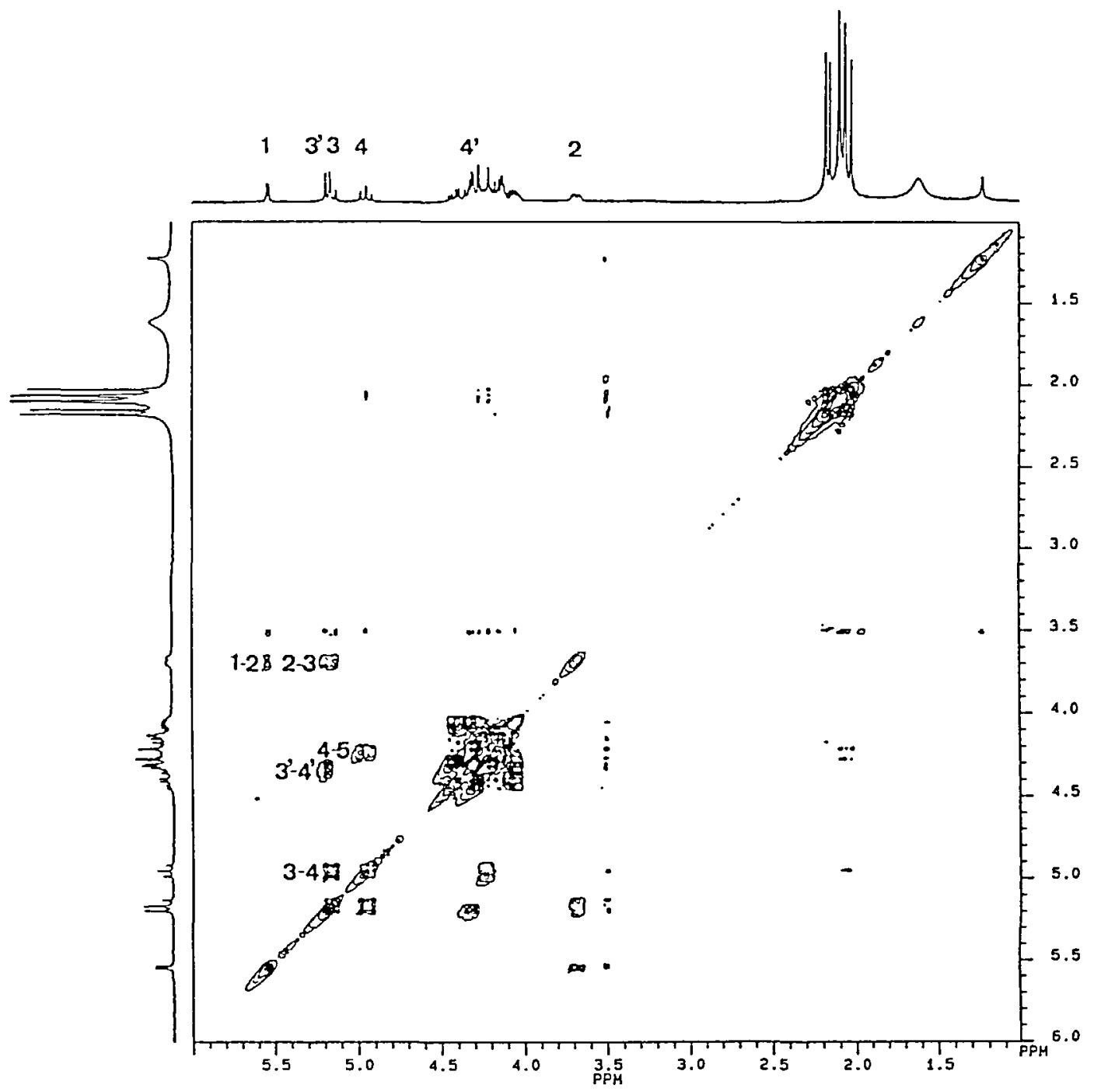

FIG. 3. $300 \mathrm{MHz}$ Two-dimensional ${ }^{1} \mathrm{H}-{ }^{1} \mathrm{H}-\mathrm{NMR}$ COSY spectrum of compound $\underline{4}$.

mixture of $2,3,4,6,4^{\prime}, 6^{\prime}$-hexa-o-acetylsucrose and $2,3,4,6,1^{\prime}, 6^{\prime}$ hexa-o-acetylsucrose have been prepared by the selective deacylation of 1 on an aluminum oxide column. ${ }^{22-26}$

More recently, the hydrolysis of octa-o-acetylsucrose by the lipases from candida cylindracea and wheat germ has been studied, and $\underline{3}, \underline{6}$ and $2,3,4,6,1^{\prime}, 3^{\prime}$-hexa-o-acetylsucrose were 


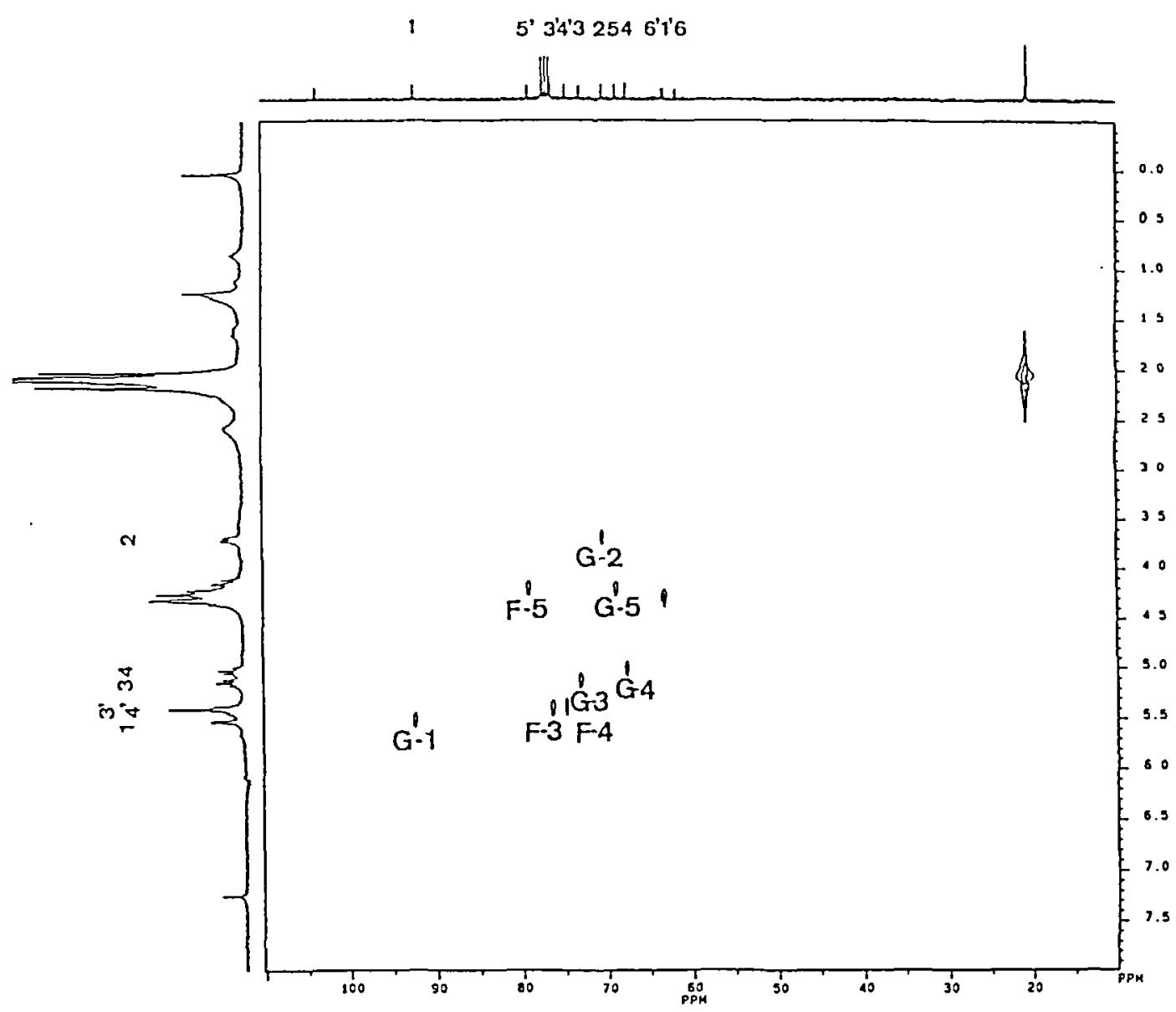

FIG. 4. ${ }^{13} \mathrm{C}-{ }^{1} \mathrm{H}$ NMR COSY spectrum of compound $\underline{2}$.

the major products. ${ }^{19}$ Judging from the selective deacylation by the aluminum oxide column and lipase-catalyzed hydrolysis, the secondary acety $\mathrm{I}$ ester at $\mathrm{C}^{-4^{\prime}}$ and primary acetyl esters at C$1^{\prime}$ and $6^{\prime}$ in the fructose moiety of 1 are the most reactive. surprisingly, both new compounds $\underline{2}$ and $\underline{4}$, which were never prepared by chemical and enzymatic methods before, could be obtained by hydrolysis with lipase AK, even though it is believed that the 2-acetyl ester in 1 is buried inside the molecule. ${ }^{1}$ It was speculated that primary acetyl groups in 1 were more easily removed and compound $\underline{3}$ was probably formed by acetyl migration 
from $\mathrm{C}-4^{\prime}$ to $\mathrm{C}-1^{\prime}$ or $6^{\prime}$. However, sucrose hepta-o-acetate which was deacylated in $\mathrm{C}-1$, or 6 or $1^{\prime}$ was not found in the lipase AKhydrolyzed reaction mixture. Therefore, compounds $\underline{2}$ and $\underline{3}$ might be formed by direct enzymatic hydrolysis, not by acyl migration. The question of acyl migration during reaction and the process of product purification is still under investigation. According to the results, lipases are versatile and can become potential catalysts for the preparation of sucrose esters which have been recognized as useful compounds for a variety of commercial applications. ${ }^{1-5}$

\section{EXPERIMENTAL}

Lipase AK (Pseudomonas Sp.) was purchased from Amano Pharm. Co., Ltd, Japan and was used for hydrolytic reactions without further purification. TLC was performed on silica gel G.60 ( $E$. Merck, FRG) precoated on glass plates with MeOH/ether (1:100) as the developing system. Optical rotations were measured on a Polartronic Universal Polarimeter (Schmidt \& Haensch, FRG). ${ }^{1} \mathrm{H}-$ NMR and ${ }^{13} \mathrm{C}$-NMR spectra were recorded with a $300 \mathrm{MHz}$ Brüker instrument. All chemical shifts are reported in ppm using tetramethylsilane as internal standard. Organic solvents were reagent grade. The substrate, octa-0-acetylsucrose (1), was synthesized by an established method ${ }^{27}$ and its ${ }^{1} \mathrm{H}$ and ${ }^{13} \mathrm{C}-\mathrm{NMR}$ spectra agreed with those published.

Enzymatic Hydrolysis of Sucrose Octaacetate : To a solution

of $1 \mathrm{~g}$ of 1 ( $2.9 \mathrm{mmol})$ in the $100 \mathrm{~mL}$ of phosphate buffer ( $\mathrm{pH} 7.5$, $0.1 \mathrm{M}$, containing $0.2 \mathrm{M} \mathrm{NaCl}$ and $3 \mathrm{mM} \mathrm{CaCl}_{2}$ ) was added $3 \mathrm{~g}$ of lipase AK (purchased from Amano, Japan). ${ }^{28}$ The mixture was stirred at $30{ }^{\circ} \mathrm{C}$. The progressing of the reaction was monitored by TLC with MeOH/ether (1: 100) as the developing system and kept under $110{ }^{\circ} \mathrm{C}$ for $10 \mathrm{~min}$ after spraying with $5 \& \mathrm{H}_{2} \mathrm{SO}_{4}$ in ethanol. After $84 \mathrm{~h}$, the reaction mixture was stopped by extracting the products with ether or ethyl acetate. ${ }^{29}$ The extract was concentrated under reduced pressure and four products were obtained in 77 of conversion, after purification by a silica gel column eluted with $\mathrm{MeOH} /$ ether $(1: 100)$. 
$3,4,6,1^{\prime}, 3^{\prime}, 4^{\prime}, 6^{\prime}$-hepta-o-acetylsucrose (2 2) (62 mg, white crystal from ether, 8 \&), mp $110-114{ }^{\circ} \mathrm{C},[a]_{0}^{25}+46.7^{\circ}$ (c1, $\mathrm{CHCl}_{3}$ ).

$2,3,4,6,1^{\prime}, 3^{\prime}, 6^{\prime}$-hepta-o-acetylsucrose ( $\left.\underline{3}\right)$ (150 mg, syrup, $208),[\alpha]_{0}^{25}+52.3^{\circ}\left(\underline{c} 2, \mathrm{CHCl}_{3}\right) ; \operatorname{lit}^{19.23}[\alpha]_{0}^{25}+53.8^{\circ}$ (co.5, $\left.\mathrm{CHCl}_{3}\right) ;[\mathrm{a}]_{0}^{25}+54.3^{\circ}\left(\mathrm{c} 0.4, \mathrm{CHCl}_{3}\right)$.

$3,4,6,1^{\prime}, 3^{\prime}, 6^{\prime}$-hexa-O-O-acetylsucrose (4) $(93 \mathrm{mg}$, white crystal from ether, 148 ) $\mathrm{mp} 128-131{ }^{\circ} \mathrm{C} ;[\mathrm{a}]_{0}^{25}+46.0^{\circ}$ ( ${ }^{1}$, $\mathrm{CHCl}_{3}$ ).

$2,3,4,6,3^{\prime}, 6^{\prime}$-hexa-o-acetylsucrose (ㅁ) (280 mg, syrup, 41 8). $[\mathrm{a}]_{0}^{25}+26.4^{\circ}\left(\underline{c} 1, \mathrm{CHCl}_{3}\right)$.

\section{REFERENCES AND FOOTNOTES}

1. R. Khan, Pure. Appl. Chem., 56, 833 (1984).

2. R. R. King, R. P. Singh, and L. A. Calhoun, Carbohydr. Res. 173, 235 (1987).

3. R. R. King, R. P. Singh, and I. A. Calhoun, Carbohydr. Res. 166, 113 (1987).

4. R. R. King, Y. Pelletier, R. P. Singh, and I. A. Calhoun, J. Chem. Soc. Chem. Commun. 1078 (1986).

5. R. Khan, Adv. Carbohydr. Chem. Biochem. 33, 278 (1976).

6. W. E. Ladner, and G. M. Whitesides, J. Am. Chem. Soc. 106, 7250 (1984).

7. P. E. Sonnet, J. Org. Chem., 52, 3477 (1987).

8. S. Koshiro, K. Sonomoto, A. Tanaka, and S. Fukui, J. Biotechology. ㄹ, 47 (1985).

9. G. Langrand, M. Secchi, G. Buono, J. Baratti, and C. Triantaphylides, Tetrahedron Lett., 26, 1857 (1985).

10. G. Kirchner, M. P. Scollar, and A. M. Klibanov, J. Am. Chem. Soc., 107, 7072 (1985).

11. M. Therisod, and A. M. Klibanov, J. Am. Chem. Soc. 108, 5638 (1986).

12. H. Seino, T. Uchibori, T. Nishitani, and S. Inamasu, J. Am. oil. Chem. Soc. 61, 1761 (1984).

13. J. F. Shaw, and A. M. Klibanov, Biotechnol. Bioeng. 29, 648 (1987).

14. F. Nicotra, S. Riva, F. Secundo, and L. Zucchelli, Tetrahedron Lett. 30, 1703 (1989). 
15. E. W. Holla, Angew. Chem. Int. Ed. Engl. 28, 220 (1989).

16. W. J. Hennen, H. M. Sweers, Y. F. Wang, and C. H. Wong, J. Org. Chem. 53, 4939 (1988).

17. S. Riva, J. Chopineau, A. P. G. Kieboom, and A. M. Klibanov, I. Am. Chem. SOC. 110, 584 (1988).

18. A. L. Fink, and G. W. HaY, Can. J. Chem. 47, 353 (1969),

19. M. Kloosterman, J. G. J. Weijnen, N. K. de Vries, J. Mentech, I. Caron, G. Descotes, H. E. Schoemaker, and E. M. Meijer, J. Carbohydr. Chem. 8, 693 (1989).

20. M. Kloosterman, M. P. de Nijs, J. G. J. Weijnen, H. E. Schoemaker, and E. M. Meijer, J. Carbohydr. Chem. 8,333 (1989).

21. (a) J. K. M. Sanders, and B. K. Hunter, Modern NMR Spectroscopy : A Guide for Chemists, Oxford University Press; Oxford, New York, Tokyo; 1987, pp 282-297. (b) T. Nishda, C. R. Enzell and G. A. Morrish, Magn. Res. Chem. 24, 179 (1986).

22. J. M. Ballard, I. Hough, and A. C. Richardson, Carbohydr. Res. 24, 152 (1972).

23. J. M. Ballard, L. Hough, and A. C. Richardson, Carbohydr. Res. 34,184 (1974).

24. A. H. Haines, Adv. Carbohydr. Chem. Biochem. 39, 13 (1981).

25. K. Capek, T. Vydra, M. Ranny and P. Sedmera, collect. Czech. Chem. Commun. 50, 2191 (1985).

26. K. Capek, M. Vodrazkova-Medonosova, J. Moravcova, and P. Sedmera, Collect. Czech. Chem. Commun. 51, 1476 (1986).

27. Linstead, R.P.; Rutenberg, A.; Dauben, W. G.; Evans, W. L., J. Am. Chem. SOC., 62, 3260 (1940).

28. Iipase $\mathrm{AK}$ is an inexpensive and crude enzyme, so the high ratio of substrate-enzyme $(1: 3$, by weight) was used in this reaction.

29. The reaction mixtures extracted using ethyl acetate or ether gave the same products after purification and analysis, although ethyl acetate is considered to be a possible acyl donor. 